\title{
Prevalence and pathology of Zschokkella nova (Myxosporea) in the liver of bullhead Cottus gobio from a polluted river
}

\author{
F. Bucher ${ }^{1}$, R. Hofer ${ }^{1}$, M. El-Matbouli ${ }^{2}$ \\ ${ }^{1}$ Institute of Zoology, University of Innsbruck, Technikerstraße 25, A-6020 Innsbruck, Austria \\ ${ }^{2}$ Institute of Zoology and Hydrobiology, University of Munich, Kaulbachstraße 37, W-8000 München 22, Germany
}

\begin{abstract}
The liver of bullhead Cottus gobio L. from a polluted river was found to be infested with Zschokkella nova Klokacewa. The moderately pathogenic plasmodia inhabited the bile and pancreatic ducts and caused a proliferation and a considerable distension of the ducts as well as metaplastic flattening of duct epithelium. Mature spores were also found in the liver parenchyma, where they were normally engulfed and destroyed by macrophages. In the absence of macrophages, however, necroses developed. Infestation of bullhead was chiefly observed in connection with sewage inflow. This phenomenon as well as the pathogenicity of the parasite are discussed.
\end{abstract}

\section{INTRODUCTION}

Sporozoa are among the most commonly encoun tered endoparasites, infesting a number of fish organs In addition to highly pathogenic forms such as Myxobolus cerebralis (responsible for whirling disease), the Myxosporea also include less harmful species, mainly coelozoic (Rogers \& Gaines 1975), such as representatives of the Zschokkella genus. A variety of endogenous and exogenous factors can favour facultative pathogenic myxosporeans and lead to serious outbreaks of disease (El-Matbouli \& Hoffmann 1986).

In the course of ecotoxicological field studies on bullhead in a polluted river, infestation of the liver with Zschokkella nova Klokacewa was found relatively often. The abundance of material examined has yielded information on the pathogenesis and the reasons for the high prevalence of the parasitization.

\section{MATERIAL AND METHODS}

In February and March 1990, we examined a total of 149 bullhead Cottus gobio L. caught at 13 of 18 different sites (this investigation was only part of a more extensive scientific project) along a ca $25 \mathrm{~km}$ stretch of the River Traun in upper Austria (mean water flow: 80 $\mathrm{m}^{3} \mathrm{~s}^{-1}$ ). The stretch of the river in question included 4 large dammed-up areas, 3 local sewage works and 2 large paper mills (Fig. 1). The sewage works discharged 300 (Site 5), 100 (Site 10) and $15 \mathrm{~kg}$ (Site 16) chemical oxygen demand (COD) $\mathrm{d}^{-1}$ into the receiving water. The paper mills discharged 750 (Site 8) and 2100 $\mathrm{kg}$ (Site 12) COD dis $\mathrm{d}^{-1}$. The fish were caught with the help of electro-shock $(4.5 \mathrm{kw})$ in the usually stony region of the river bank. Body length, weight, sex and liver somatic index (liver wt $\times 100 /$ body $w t$ ) were recorded immediately.

For histological studies the liver (in some cases with associated pancreatic tissue) was fixed in $5 \%$ buffered formaldehyde ( $0.1 \mathrm{M}$ phosphate buffer, $\mathrm{pH} 7.4)$. Pieces of the liver tissue ( 1 to $2 \mathrm{~mm}$ thick) were then dehydrated in increasing percentages of ethanol and embedded in polyethylene glycol-methacrylate. Sections of $3 \mu \mathrm{m}$ thickness were routinely stained with haematoxylin/eosin, May-Grünwald/Giemsa and periodic acid-Schiff (PAS). Von Kossa stain for calcium was done on selected sections (Burck 1982).

For enzyme histochemical examination, all steps of the preparation were carried out on ice or at $4{ }^{\circ} \mathrm{C}$. The fresh liver tissue was cut into small pieces ( 1 to $2 \mathrm{~mm}$ thick) and fixed for $3.5 \mathrm{~h}$ in $5 \%$ paraformaldehyde buffered with $0.075 \mathrm{M}$ cacodylate buffer, $\mathrm{pH} 7.4$. After thorough washing with buffer, the tissue pieces were dehydrated and embedded in polyethylene glycolmethacrylate. The enzyme-histochemical staining of 


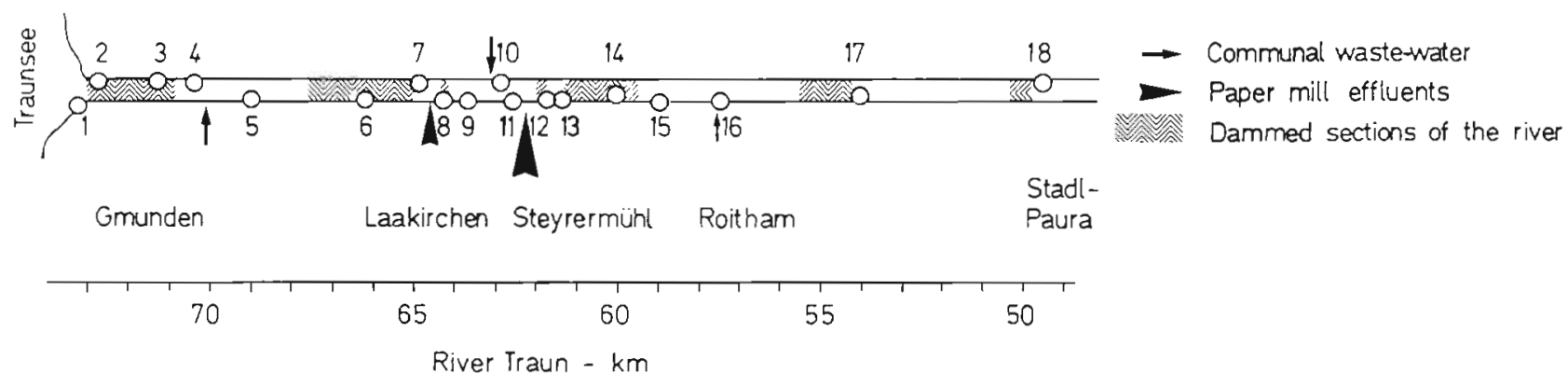

Fig. 1. Schematic representation of the experimental section of the River Traun, Austria

alkaline phosphatase (Burck 1982), acid phosphatase (Lojda et al. 1976) and myeloperoxidase (Gerrits 1983) was carried out on sections cut to $4 \mu \mathrm{m}$ thickness. Following the acid phosphatase and myeloperoxidase staining, some of the sections were counterstained with haematoxylin according to Gill (Gerrits 1983).

Identification of the parasite. Spores of 7schokkella nova were mechanically isolated, concentrated (infested liver was homogenized, filtered, centrifuged and the pellets resuspended in isotonic phosphate buffer) and identified by measuring with a computer system (Commodore PET 3001, Leitz) combined with a Leitz microscope.

\section{RESULTS}

On the basis of the characteristics listed in Table 1, the myxosporean parasite found in the liver of the bullhead could be identified as Zschokkella nova.

Table 1. Zschokkella nova. Description of the parasite

\begin{tabular}{|c|c|}
\hline \multicolumn{2}{|l|}{ Location } \\
\hline Plasmodia & Bile ducts, pancreatic ducts \\
\hline Spores & $\begin{array}{l}\text { Liver parenchyma, bile ducts, pan- } \\
\text { creatic ducts }\end{array}$ \\
\hline $\begin{array}{l}\text { Description of } \\
\text { plasmodium }\end{array}$ & $\begin{array}{l}\text { Elongated oval, flattened, weakly } \\
\text { stained matrix, polysporous, ecto- and } \\
\text { endoplasm not discernible, size vari- } \\
\text { able }\end{array}$ \\
\hline $\begin{array}{l}\text { Description of } \\
\text { spores }\end{array}$ & $\begin{array}{l}\text { Ellipsoidal, rounded ends, polar cap- } \\
\text { sules almost spherical, } 4-5 \text { polar fila- } \\
\text { ment turns }\end{array}$ \\
\hline $\begin{array}{l}\text { Dimensions of } \\
\text { spores }(n=10)\end{array}$ & $\begin{array}{l}\text { Length: } 10.55 \pm 0.49 \mu \mathrm{m}_{i} \text { width: } 5.92 \\
\pm 0.30 \mu \mathrm{m}_{i} \text { length of polar capsules: } \\
2.80 \pm 0.41 \mu \mathrm{m}\end{array}$ \\
\hline
\end{tabular}

\section{Distribution of Zschokkella nova infestation in the river}

The frequency of infestation with Zschokkella nova was roughly equal in the 2 sexes $(16 \%$ of females, $n=$ $73,17 \%$ of males, $\mathrm{n}=76$ ), although the individual bullhead populations from the stretch of the river studied exhibited different degrees of parasitization (Fig. 2). Of the fish taken from the sections of the river upstream of (Sites 1 to 3 ) or at greater distances downstream (Sites $16 \& 18$ ) of the larger sewage inflows, none of the 66 individuals examined harboured $Z$. nova. The parasite was first encountered after the entry of effluents from a large collective sewage plant (Site 5). The highest incidence of parasitization (80\%) was found in the following reservoir region (Site 6). In the vicinity of 2 large paper mills (Sites 9 to 15), the parasite was also found in at least $20 \%$ of the individuals, whereby the additional inflow from a sewage plant led to a local rise in incidence of infestation to $50 \%$ (Site 10). Not until a distance of $\mathrm{ca} 5 \mathrm{~km}$ from the second paper mill (Site 16) were the parasites no longer found, in spite of the addition of emissions from a small sewage plant.

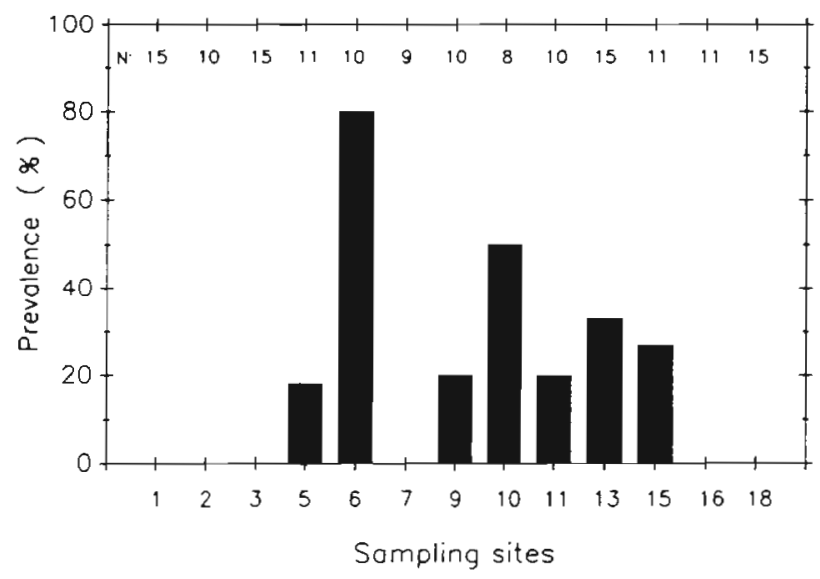

Fig. 2. Cottus gobio infested with Zschokkella nova. Prevalence of infestation (percentage of infested bullhead at each sampling site) in the experimental section of the river

\section{Macroscopic observations}

The colour of the liver ranged from brownish-red to yellowish, depending primarily on the glycogen content. Macroscopically, no differences in appearance could be 
found between infested and non-infested livers, nor were there any obvious differences in the size and colour of the gall bladder. The liver somatic index was not significantly changed by the presence of Zschokkella nova (average: 3.2 for females, 1.5 for males).

\section{Histopathology}

In the bile and pancreatic ducts, mature spores and pre-sporulating and sporulating plasmodia of Zschokkella nova were present. In the liver parenchyma, however, only mature spores of $Z$. nova were found.

The presence of, for the most part, relatively large and often multiple plasmodia resulted not only in severe distension and proliferation of the bile ducts, but also in attenuation and flattening of their epithelium (Fig. 3). A distinct increase in the activity of acid phosphatase in the latter was also found (Fig. 4). Usually a slight fibrosis was present in the pericholangiolar area.

Mature spores were also found in the liver parenchyma, causing an extensive fibrosis (Fig. 6) or a distinct pericholangitis. Only isolated granulocytes were identifiable (using the myeloperoxidase reaction); the majority of the inflammatory infiltrates consisted of macrophages (Fig. 4) and, in only a few cases, of lymphocytes. In the liver parenchyma, almost all of the spores released were phagocytozed by macrophages, which in many cases formed large granulomatous aggregations, mostly in the immediate vicinity of bile ducts (Figs. 4 \& 5) and sometimes showing calcification (Fig. 6). The macrophages could be identified histochemically due to their particularly high acid phosphatase activity (Fig. 4). In some cases, where no defence by macrophages was seen, free spores elicited severe focal necrosis in the liver parenchyma (Fig. 7).

Histochemical demonstration of the alkaline phosphatase localized in the sinusoidal endothelium and in the bile canaliculi gave an indication of the structural integrity of the liver parenchyma. In some cases, the histopathological alterations had produced extensive disruption of the liver architecture (Fig. 8), occupying up to $20 \%$ of the cross-section of the organ. Compared with infested bullhead liver, the parenchyma of uninfected liver showed a different histopathological pattern (slight fibrosis, fatty degeneration and necrosis of single hepatocytes), but no alterations of the bile ducts.

The pancreatic tissue was only examined in cases where it accidentally remained attached to the liver material. The pancreatic ducts showed similar changes as the bile ducts: proliferation, dilatation, metaplasia of the epithelium, periductular fibrosis. In the surrounding pancreatic tissue, however, no mature spores were detectable.

\section{DISCUSSION}

Infestation with parasites is the result of an interplay between environment, parasite and fish. This means

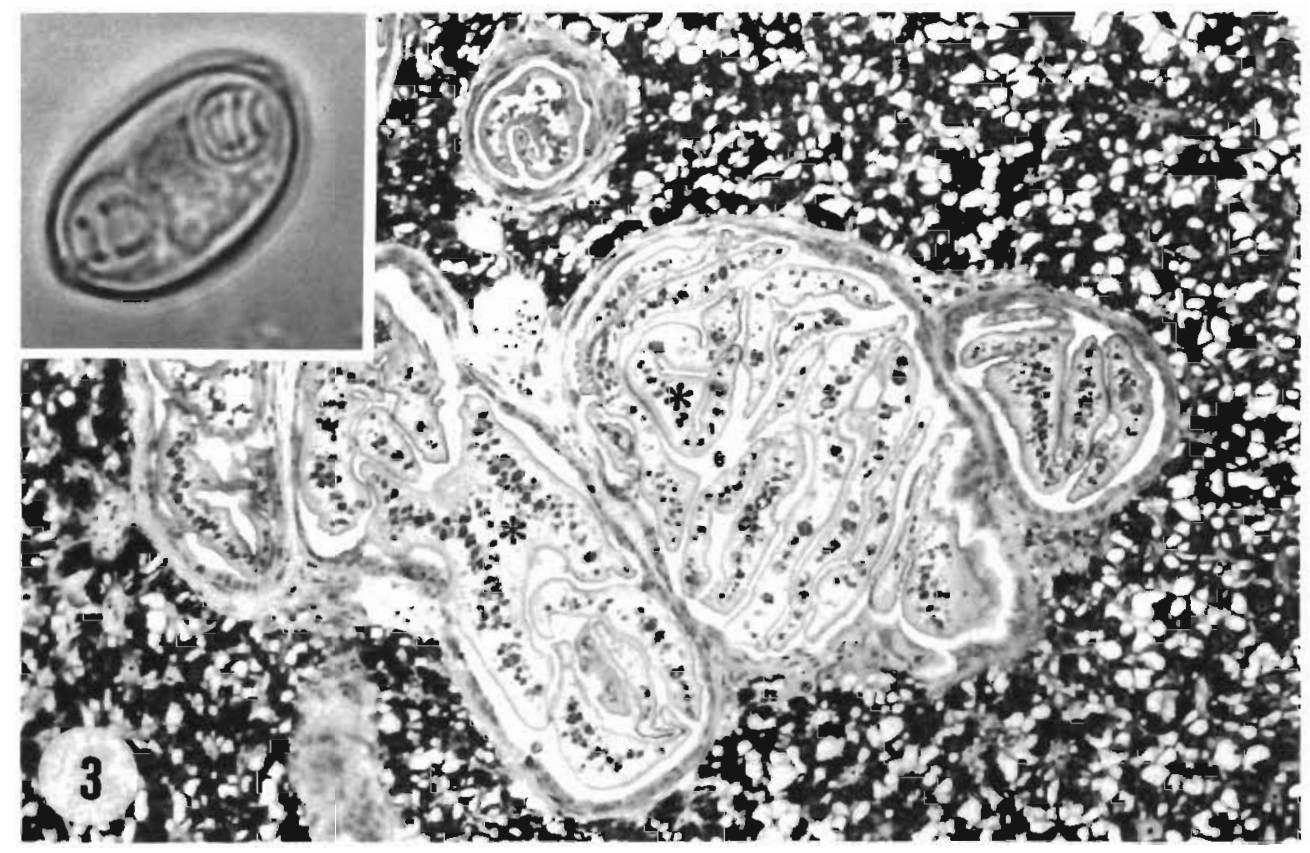

Fig. 3. Cottus gobio infested with Zschokkella nova. Plasmodia (*) in greatly widened bile ducts with flattened epithelium in the liver of a bullhead. May-Grünwald/Giemsa, $\times 200$. Inset: fresh spore, $\times 2300$ 


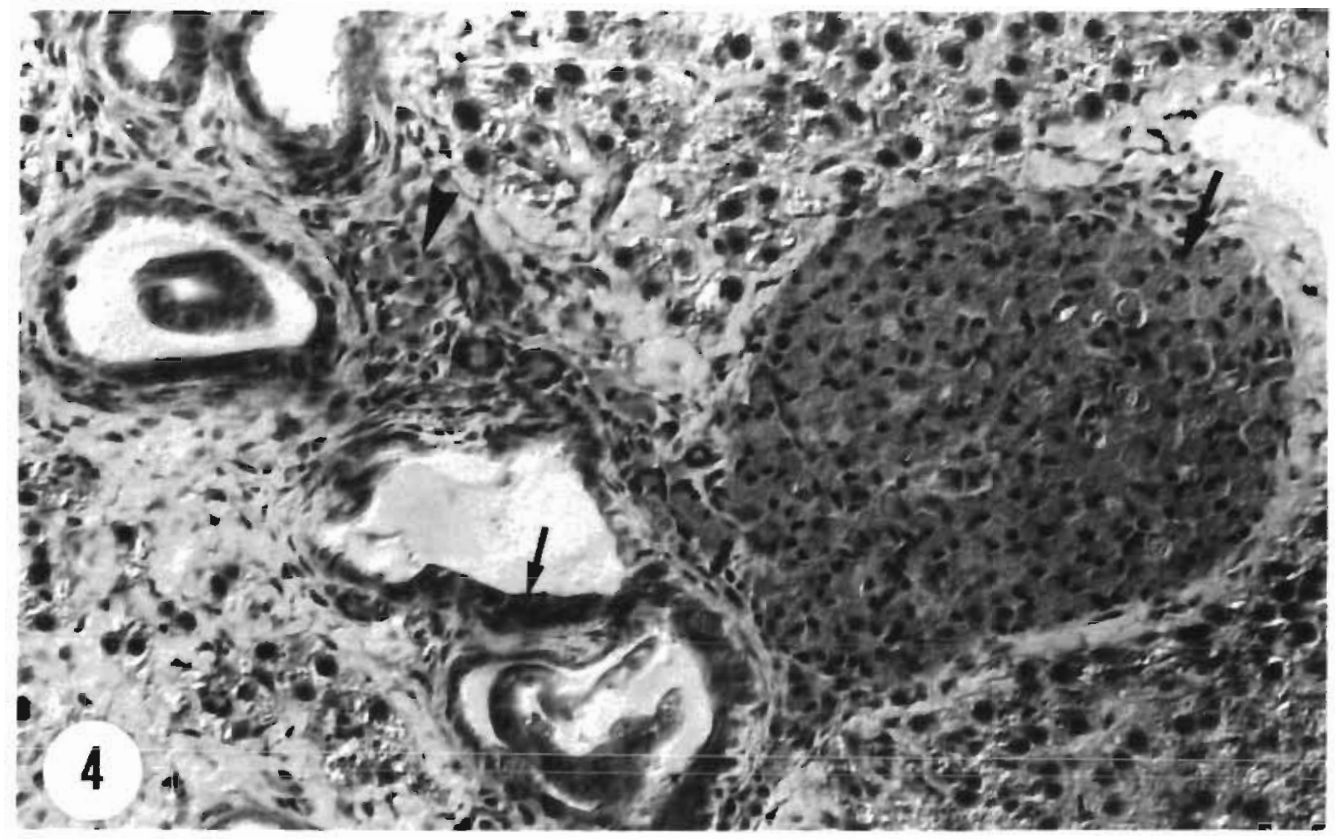

Fig. 4. Cottus gobio infested with Zschokkella nova. Acid phosphatase reaction in the liver of infested bullhead. The patches of macrophages (large arrow), the inflammatory infiltrate surrounding the bile ducts (arrowhead) and the duct epithelium (small arrow) are clearly acid-phosphatase positive; $\times 400$

that the occurrence of a parasite may depend, among other factors, on the presence of intermediate hosts, the degree of water pollution, and the state of health or powers of resistance of the host (Schäperclaus 1979, ElMatbouli \& Hoffmann 1989, Lehtinen 1989). In the present investigation, infestation with Zschokkella nova was encountered in the stretches of river rendered eutrophic by sewage inflow. Eutrophication of water also leads to corresponding changes in the invertebrate fauna. Within the immediate sphere of influence of the sewage input, an abnormal multiplication of oligochaetes is generally observed (Odzuck 1982); together with other benthic invertebrates they serve as food for the bottom-dwelling bullhead (Welton et al. 1983). Since infective stages of myxosporeans develop in oligochaetes (El-Matbouli \& Hoffmann 1989, Yokoyama et al. 1991), the site-specific diet may be responsible for the $Z$. nova infection. The bullhead from Sites 6, 10 \& 13 exhibited a higher intensity of parasitization. Since these were populations in which histopathological changes not attributable to parasites were found in various organs (Hofer \& Bucher 1992), the observed higher intensity of parasitization could be due to a debilitating effect of the sewage on the fish. It is well known that pollutants suppress the defence system and predispose fish to disease (Pickering \& Pottinger 1989).

In freshwater fish, the organs reported as being most frequently infested by myxosporeans are the gills and gall bladder (Rapacz et al. 1973, Rogers \& Gaines 1975). Schäperclaus (1979) and Roberts (1985) consider the most likely route of entry for myxosporeans to be via the intestine and bloodstream. Markiw (1989) and El-Matbouli et al. (1992) have shown that initial penetration of fish tissues by myxosporeans takes place in fins, gills, skin and intestine. As in other species of myxosporeans, the life cycle and mode of transmission of Zschokkella nova are unknown. The plasmodia of this parasite mature in the bile duct system and pancreatic ducts. Following sporulation the mature spores can be found in the neighbouring tissue, in all probability primarily due to the obstruction of bile duct walls by the large plasmodia. Some spores, however, may have reached the liver via the blood stream. The histopathological changes in the bile ducts elicited by $Z$. nova very closely resemble those described in connection with the infestation of five-beard rocklings Ciliata mustela L. by Zschokkella russelli (Davies 1985. Davies \& Sienkowski 1988). The marked elevation of acid phosphatase activity in the metaplastic bile duct epithelium suggests destruction of obsolete parts of the epithelial cells themselves or breakdown of material taken up from the lumen by endocytosis (Alberts et al. 1989). Unlike Davies (1985), however, who did not see the parasite free in liver tissue, we regularly observed mature spores in the liver parenchyma. In the case of $Z$. nova, therefore, a distinction must be made between the pathogenicity of plasmodia and that of mature 


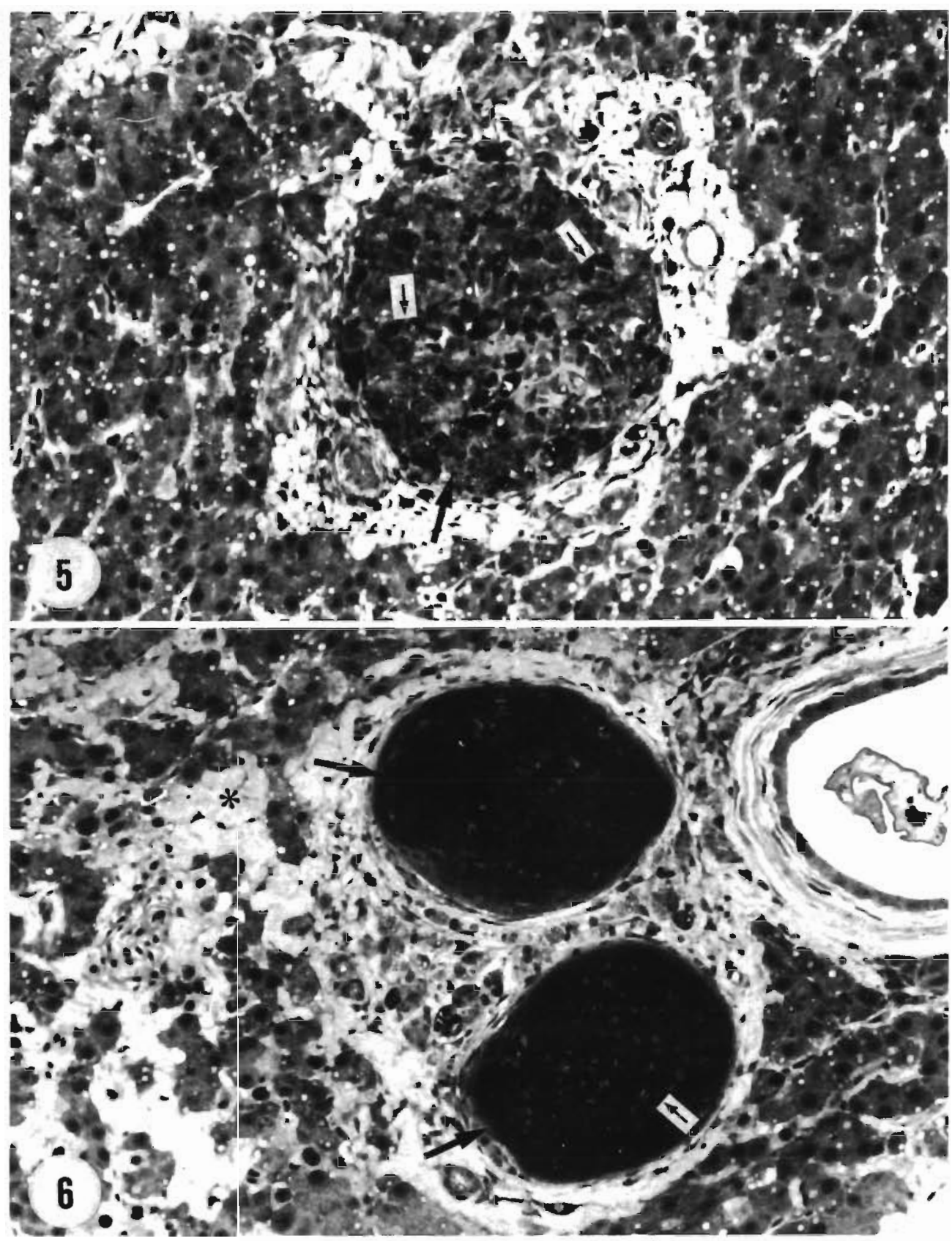

Figs. 5 \& 6. Cottus gobio infested with Zschokkella nova. Fig. 5. Macrophage aggregate (large arrow) in the liver of a bullhead showing phagocytozed spores of $Z$. nova (small arrows). May-Grünwald/Giemsa, $\times 400$. Fig. 6. Calcifying patches of macrophages (large arrows), in which numerous spores of $Z$. nova are still recognizable (small arrow). (*) Advanced fibrosis of the surrounding liver tissue. May-Grünwald/Giemsa, $\times 400$ 


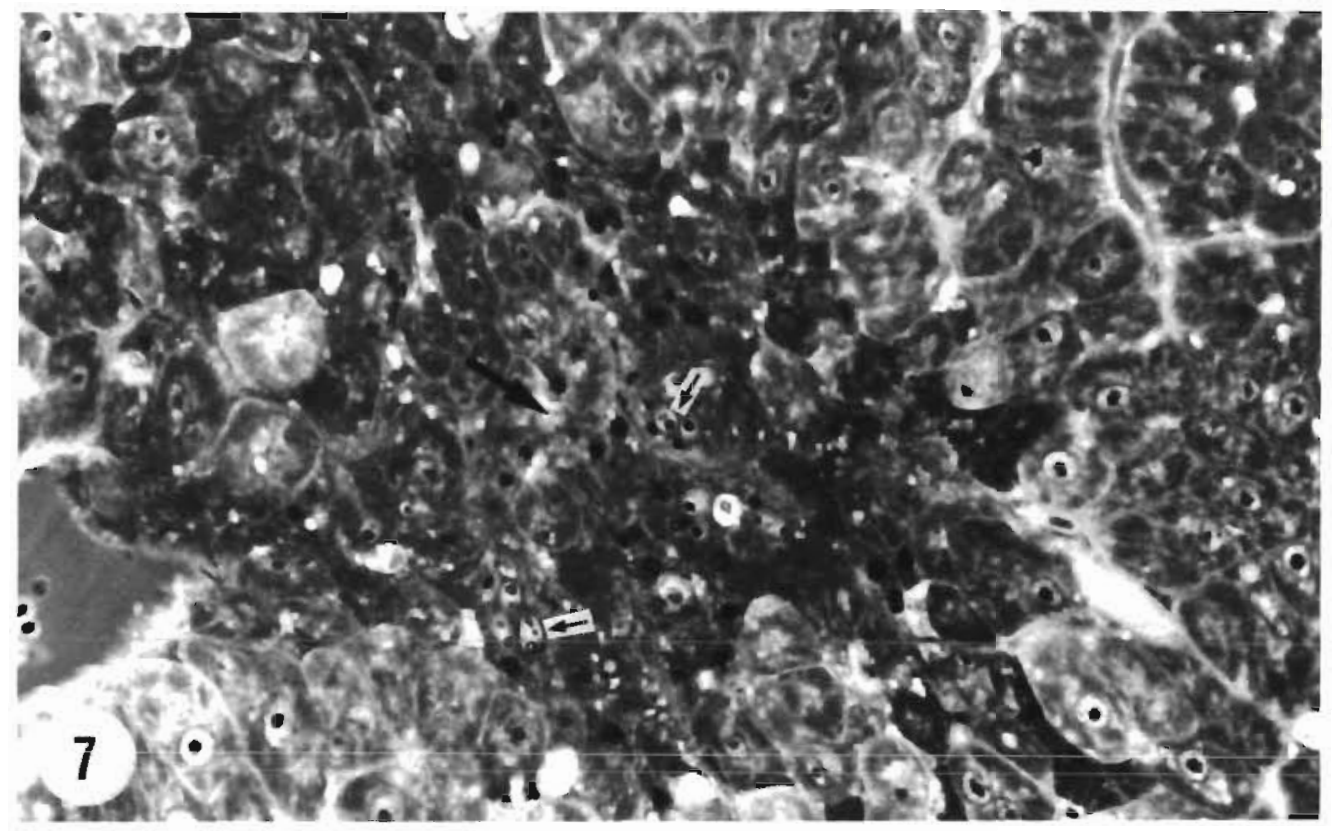

Fig. 7. Cottus gobio infested with Zschokkella nova. Severe necrosis (large arrow) in the liver parenchyma, elicited by mature spores of Z. nova (small arrows). May-Grünwald/Giemsa, $\times 500$

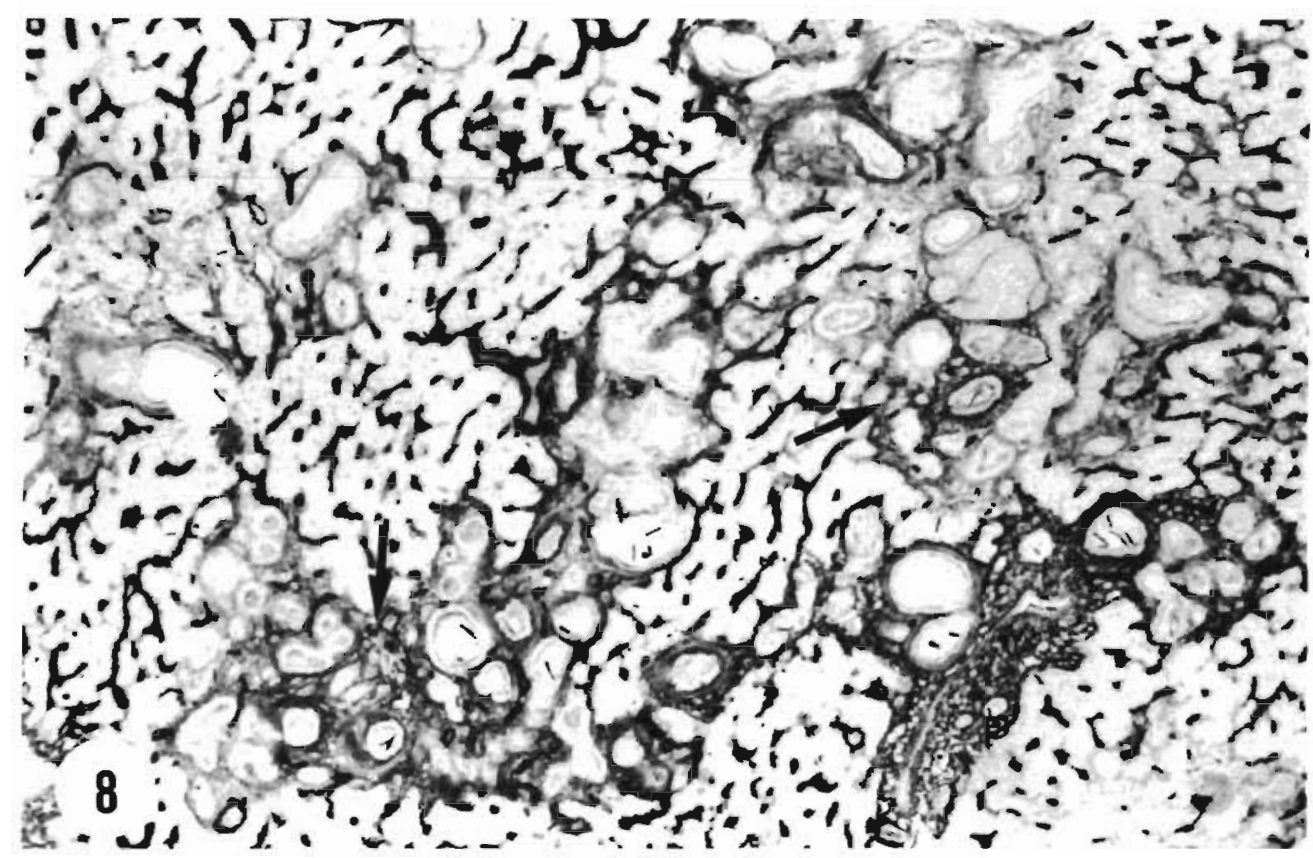

Fig. 8. Cottus gobio infested with Zschokkella nova. Alkaline phosphatase reaction in an infested bullhead liver. Pathologically altered areas are recognizable as irregularities (arrows) in the liver parenchyma, $\times 125$ 
spores. Rogers \& Gaines (1975) described the coelozoic species of Myxosporea - in contrast to the histozoic forms - as not particularly pathogenic. In the case of $Z$. nova, the coeloic plasmodia do, in fact, have relatively little pathogenic effect, mostly confined to the bile ducts. Some of the fibrotic alterations and cell deteriorations seen in the parenchyma are probably reactions to the excessive widening of the infested ducts. However, in the liver parenchyma, mature spores of this species cause a strong and efficient defence reaction. If the defence mechanisms are inefficient (absence of macrophage invasion), the spores bring about severe necrosis in the liver parenchyma. Since fish exposed to the stress of water of inferior quality frequently have a poor defence system (immunosuppression; Peters 1979), the secondary consequences of water contamination elicited by $Z$. nova may be of ecological significance.

Acknowledgements. This investigation was supported by the Bundesministerium für Umwelt, Jugend und Familie and by the Land Oberosterreich. We thank Joy Wieser for translating the manuscript.

\section{LITERATURE CITED}

A.lberts, B., Bray, D., Lewis, J., Raff, M., Roberts, K., Watson, J. D. (1989). Molecular biology of the cell, 2nd edn. Garland Publishing, New York

Burck, H. C. (1982). Histologische Technik, 5. Aufl. Georg Thieme Verlag, Stuttgart

Davies, A. J. (1985). Zschokkella russelli Tripathi (Myxozoa: Myxosporea) from the five-bearded rockling, Ciliata mustela L., (Teleostei: Gadidae) in Wales. J. Fish Dis. 8: 299-308

Davies, A. J., Sienkowski, I. K. (1988). Further studies on Zschokkella russelli Tripathi (Myxozoa: Myxosporea) from Ciliata mustela L. (Teleostei: Gadidae), with emphasis on ultrastructural pathology and sporogenesis. J. Fish Dis. 11: 325-336

El-Matbouli, M., Fischer-Scherl, T., Hoffmann, R. (1992). Present knowledge on life cycle, taxonomy, pathology and therapy of some Myxosporea spp. important for freshwater fish - a review. A. Rev. Fish Dis. 2: 367-402

Responsible Subject Editor: W. Körting, Hannover, Germany
El-Matbouli, M., Hoffmann, R. (1986). Verbreitung von Myxosporidien unter freilebenden Fischen in Bayern. DVG. Tagung der Fachgruppe Fischkrankheiten, München, p. $63-76$

El-Matbouli, M., Hoffmann, R. (1989). Experimental transmission of two Myxobolus spp. developing bisporogeny via tubificid worms. Parasitol. Res. 75: 461-464

Hofer, R., Bucher, F. (1992). Ökotoxikologische Untersuchungen an Koppen (Cottus gobio L.) eines abwasserbelasteten Flusses. Fischökologie (in press)

Gerrits, P. O. (1983). Verfahren zur Färbung von Gewebe, das in 2-Hydroxyethyl-Methacrylat eingebettet wird. Sonderdruck f. Kulzer \& Co. GmbH, Wehrheim

Lehtinen, K.-J. (1989). Survival, growth and disease of threespined stickleback, Gasterosteus aculeatus L., brood exposed to bleached kraft mill effluents (BKME) in mesocosms. Annls Zool. fenn. 26: 133-143

Lojda, Z., Gossrau, R., Schiebler, T. H. (1976). Enzymhistochemische Methoden. Springer Verlag, Berlin

Markiw, M. E. (1989). Portals of entry for salmonid whirling disease in rainbow trout. Dis. aquat. Org. 6: 7-10

Odzuck, W. (1982). Umweltbelastungen: Belastete Ökosysteme. Verlag Eugen Ulmer, Stuttgart

Peters, G. (1979). Zur Interpretation des Begriffs 'Stress' beim Fisch. Fisch und Umwelt $7: 25-32$

Pickering, A. D., Pottinger, T. G. (1989). Stress responses and disease resistance in salmonid fish: effects of chronic elevation of plasma cortisol levels. Fish Physiol. Biochem. 7: 253-258

Rapacz, E., Iversen, E. S., Feigenbaum, D. (1973). Zschokkella foridanae sp. n. (Myxosporidae) from the goldspotted killifish, Floridichthys carpio (Günther). J. Protozool. 20 (3) 367-369

Roberts, R. J. (1985). Grundlagen der Fischpathologie. Paul Parey Verlag, Berlin

Rogers, W A., Gaines, J. L. (1975). Lesions of protozoan diseases in fish. In: Ribelin, W. E., Migaki, G. (eds.) The pathology of fishes. Univ. of Wisconsin Press, Madison, $p$. $117-141$

Schäperclaus, W. (1979). Fischkrankheiten. Akademie Verlag, Berlin

Welton, J. S., Mills, C. A., Rendle, E. L. (1983). Food and habitat partitioning in two small benthic fishes, Noemacheilus barbatulus (L.) and Cottus gobio L. Arch. Hydrobiol. 97(4): 434-454

Yokoyama, H., Ogawa, K., Wakabayashi, H. (1991). A new collection method of actinosporeans - a probable infective stage of myxosporeans to fishes - from tubificids and experimental infection of goldfish with the actinosporean, Raabeia sp. Gyobyo Kenkyu 26(3): 133-138

Manuscript first received: March 31, 1992

Revised version accepted: July 15, 1992 